\title{
FACTORS THAT RELEVANT TO THE QUALITY OF LIFE OF BREAST CANCER PATIENTS
}

\author{
Haris $^{1}$, Laili Rahayuwati ${ }^{2}$, Ahmad Yamin ${ }^{3}$ \\ ${ }^{1}$ Faculty of Nursing Universitas Padjadjaran, Bandung, Indonesia \\ Correspondence : hariskasuhe@gmail.com
}

\begin{abstract}
Breast cancer is a health problem since so many years ago especially to women. In 2013, Basic Health Research (Riskesdas) showed that the number of national breast cancer prevalence was the second most numerous patients in the world especially attacked women in Indonesia. The common problems experienced by breast cancers patients is the decrease of life quality of the patients. The purpose of this research was to identify factors related to the life quality of the breast cancers patients in Bandung city. This research used cross sectional method. The determination of life quality based on Quality of Life Cancer Survivor Version (QOL-CSV). Accidental sampling was used to choose samples. This research was taken place in four rumah singgah (shelters) of breast cancer located in Bandung city. There were 30 women involved in this study. Inclusive criterion in this research was the patients of breast cancers who are undergoing medications such as surgery, chemotherapy, or radiotherapy, who are willing to be the respondents voluntary. Result of normality test included age factor, marital age and firts time pregnance. Multivariate test used in this research was the linear regression analysis. Based on the result of bivariate analysis, age factor and frequency of pregnancy had positive correlated $(p<0.05)$ to the life quality of breast cancer patients, while menarche had a negative correlated. Regression linear result was determined to life quality factor $(p<0,05)$ including age factor, marital age and pathology anatomy result. Half of the result of coefficient correlation showed a strong relationship in the quality of life of breast cancer patients. This Research showed that some of the reproduction factors related to the quality of life. Some factors are contributed to the quality of life of breast cancer patients such as age of the patient, marital age and result of pathology anatomy (cancer stage). This research needs more in-depths studies toward the quality of life of breast cancers patients as well as efforts of intervention to increase the quality of life of breast cancers patients.
\end{abstract}

Keywords: breast cancer, quality of life, reproductive factors

\section{INTRODUCTION}

Breast cancer is spreading like a rash for women today,. In 2012, there were 1.7 million new breast cancer patients worldwide. The number of breast cancer incidents was 39 up to 43.2 per 100.000 people. On the other hand, the mortality rate of breast cancer was $12.3 \%$ to 12.9\% from all of current breast cancer patients (Advanced Breast Cancer Conference, 2015). In 2013, Basic Health Research (Riskesdas) showed the number of national cancer prevalence as much as 140 per 100.000 people, indicating 347.792 cancer patients in that year alone. The highest cancer prevalence was cervix cancer with 80 per 100.000 people, followed by breast cancer with 50 per 100.000 .

Today, the cause of breast cancer is yet scientifically proven, but some of its triggering factors already are, one of which is reproductive factor. It include the less-than-12- 
years-old of menarche, varieties, first pregnancy age for 20- to 30-years-old mother, and nonbreastfeeding mother with less than 12-months-old child (Ardiana, Negara \& Sutisna, 2013). However, some other relevant conditions to breast cancer incidents include obesity, oral contraception, and hormonal therapis (Anothainsintawee, et al., 2015; James, et al.)

When the patients begans to feel the sign of early stadium of breast cancer, they did not seeking to get medical service but they decided to look for traditional treatment or complementary treatment as first choice. If it's not effective, they visited health services to get medical service. Sometime their condition was severe. Some of them do combinate the conventional treatment with traditional treatment or complementary treatment. From health professional's views, they expressed that coventional treatment is importence and must become first choice to breast cancer treatment and they expect for the future, an effective and appropriate therapy can be found with less side effect with combination of the conventional terapy and complementary terapy (Rahayuwati, et al., 2016)

The most common problem faced by breast cancer patients is the decrease of their quality of life. Patients undergoing chemotherapy shows lower degree of the quality of life than those who are not (Purkayastha, 2017; Maly et al., 2015). The quality of life of breast cancer patients undergoing breast cancer medication is dependent on the stage of stadium and the chemotherapy cycle. If the patients is undergoing chemotherapy, then the cycle will add up, thus the life quality will be better (Nurhasanah, 2014). The patient's quality of life can be related to the current treatment he/she is undergoing, combined by conventional and complementary treatment, as well as family support (Irawan, Rahayuwati \& Yani, 2017) including factors related to social support (Yan et al., 2016).

Several changes faced by the breast cancer patients including physical, psychological, social, and spiritual aspects. The physical change comprises of change in fertility and menstruation cycle, fatigue level, and pain. The psychological change including fear of his 
own illness, pressure during surgery, fear of enduring other types of cancer, disruption of self-image, and fear of tomorrow. The social change comprises of role shift in family and temporary pressure. The spiritual change comprises of the feeling of uncertainties of and inabilities to attend religious activities (Copra \& Kamal, 2012). Generally, some conditions faced by the patients also include high level of fatigue, anxiety, stress, depression, pain, and sleeping trouble (Kim et al., 2017; Ng et al., 2015).

Many factors determine the quality of life of breast cancer patients. However, not many have identified the reproduction factors related to the quality of life, hence this becomes the researcher's drive to identify whether the reproduction and other factors contributing to the quality of life. The aim of this research was to identify factors relevant to the quality of life of breast cancer patients in Bandung city.

\section{METHODS}

This research applied a cross-sectional method by looking at the correlation between various factors and the quality of life of breast cancer patients. The factors include age, education level, marital status, occupation, menarche (first age of menstruation), marital age, variety, breastfeeding duration, undergoing medication, contraception and check result of anatomypathology (breast cancer stadium). The determination of the patient's quality of life based on the Quality of Life Cancer Survivor Version (QOL-CSV) published by National Medical Center and Beckman Research Institute City of Hope consisting of 41. The QOL-CSV instrument measures four aspects of the quality of life on breast cancer patients: physical, psychological, social, and spiritual. This instrument has applied an interval scaling, the respondents pick a list of responses using semantic differential scale within the range of 0 to 10. Respondents determine the scale based on what they felt. Each question has been translated to Indonesian by translating experts in Language Center Universitas Padjadjaran. 
This was followed by face validity testing, which resulted in several linguistics structures in questionnaires adjusted with conditions in Indonesia. Changes were made to avoid misinterpretation or confusion; for instance, "spiritual contemplation" was changed to "meditation by remembering God (dzikir)" and "positive side" to "essence."

The sampling technique applied the accidental sampling method. This was done in four transit houses in Bandung. Inclusive criteria in this research included breast cancer patients undergoing breast cancer medication such as surgery, chemotherapy, or radiotherapy, and those who were available to become respondents. On the other hand, exclusive criteria included early-stage and final-stage breast cancer patients. The number of respondents was 30 women. Three factors showed that data were normally distributed based on KolmogorovSmirnov testing with sig value $>0.05$, including respondent's age, marital age, and first pregnant age and then the bivariate analysis uses parametrical (Pearson's) testing. For data has not normally distributed, the bivariate analysis uses non-parametrical (Spearman's) testing for . The multivariate testing used a linear regression analysis to find the contribution to the quality of life and to test how strong the correlation was, thus the correlation coefficient assessment was applied. This research obtained an ethical approved from the health the research ethics committee faculty of medicine Universitas Padjadjaran Bandung base on number 70/UN6.C10/PN/2018 issued 23 Januari 2018.

\section{RESULTS}

Table 1. Characteristic of Respondents $(\mathrm{N}=30)$

\begin{tabular}{lcc}
\multicolumn{1}{c}{ Characteristics } & \multicolumn{2}{c}{ Respondent $(\mathbf{N = 3 0})$} \\
& $\mathbf{F}$ & $\mathbf{\%}$ \\
\hline Age & \multicolumn{2}{c}{ Mean : 48,87} \\
& Min-Max $32 \quad 68$ \\
\hline Education & & \\
Elementary & 21 & 70.0 \\
Middle & 4 & 13.3 \\
High & 4 & 13.3 \\
University & 1 & 3.6 \\
\hline Marital Status: & \multicolumn{3}{c}{} \\
\hline
\end{tabular}




\begin{tabular}{|c|c|c|}
\hline Married & 21 & 70 \\
\hline Widowed & 9 & 30 \\
\hline \multicolumn{3}{|l|}{ Occupation: } \\
\hline Employed & 9 & 30 \\
\hline Unemployed & 21 & 70 \\
\hline \multicolumn{3}{|l|}{ Therapy: } \\
\hline Post-surgery & 4 & 13.3 \\
\hline Chemoterapy & 16 & 53.3 \\
\hline Radioterapi & 5 & 16.7 \\
\hline Out patient & 5 & 16.7 \\
\hline \multicolumn{3}{|l|}{ Contraception: } \\
\hline Pill & 6 & 20 \\
\hline Injection & 9 & 30 \\
\hline IUD & 2 & 6.7 \\
\hline Implant & 3 & 10 \\
\hline Non-Family Planning & 10 & 33.3 \\
\hline \multicolumn{3}{|l|}{ Cancer Stadium: } \\
\hline Stadium II & 20 & 66.7 \\
\hline Stadium III & 10 & 33.3 \\
\hline \multicolumn{3}{|l|}{ Reproduction Status: } \\
\hline First Menstruation & \multicolumn{2}{|c|}{ Mean : 13,63 } \\
\hline Marital Age & \multicolumn{2}{|c|}{ Mean : 19,23 } \\
\hline First Pregnancy Age & \multicolumn{2}{|c|}{ Mean : 21,57 } \\
\hline Pregnancy Frequency & \multicolumn{2}{|c|}{ Mean : 3,63 } \\
\hline $\begin{array}{l}\text { Breastfeeding Period } \\
\text { (months) }\end{array}$ & \multicolumn{2}{|c|}{ Mean : 18,80} \\
\hline
\end{tabular}

Table 1 shows that the average of respondent's age was 48.87 years old, elementary school graduates (70\%), married (70\%), unemployed (70\%), undergoing chemotherapy (53.3\%), not joining Family Planning (33.3\%), Stage II stadium breast cancer based on anatomy-pathology testing (66.7\%). Meanwhile, for the reproduction status, the first menstruation occurred at 13.6 years old in average, married at 19.23 years old, first pregnant at 21.57 years old, has been pregnant 3.63 times, and breastfeeding period for 18.80 months.

\section{Table 2 Result of Bivariate Testing with The Pearson Formula}

\begin{tabular}{lcc}
\hline \multicolumn{1}{c}{ Risk Factor } & Correlation & Sig \\
\hline Age & 0.464 & $0.010^{*}$ \\
Age when married & -0.396 & $0.030^{*}$ \\
First pregnancy age & -0.328 & 0.77 \\
\hline
\end{tabular}

sig value $<0.05$ 
Table 2 shows the result of parametrical bivariate analysis (Pearson), with the positively correlative factor $(\mathrm{p}<0.05)$ on the quality of life of breast cancer patients was age with p-value 0.010. Meanwhile, first pregnancy age was negatively correlated with p-value 0.030 .

Table 3 Result of Bivariate Testing with Spearman's Test

\begin{tabular}{lcc}
\hline \multicolumn{1}{c}{ Risk Factor } & Correlation & Sig \\
\hline Education & -0.174 & 0.358 \\
Marital Status & -0.113 & 0.550 \\
Occupation & -0.029 & 0.887 \\
First Menstruation Age & 0.112 & 0.556 \\
Pregnancy Frequency & 0.441 & $0.015^{*}$ \\
Breastfeeding Period & -0.123 & 0.518 \\
Current Treatment & 0.158 & 0.404 \\
Contraceptives & -0.045 & 0.812 \\
Cancer Stadium & -0.127 & 0.505 \\
\hline
\end{tabular}

sig value $<0.05$

Table 3 shows the result of non-parametrical bivariate analysis (Spearman's) with pregnancy frequency with $\mathrm{p}$-value 0.015 , being the positively correlated factor $(\mathrm{p}<0.05)$ to the quality of life of breast cancer patients. 
Table 4 Multivariate Testing with Regression and Coefficient Corelation

\begin{tabular}{|c|c|c|}
\hline Risk Factor & $\begin{array}{c}\text { Coefisien } \\
\text { corelation } \\
(\mathrm{R})\end{array}$ & Sig \\
\hline Age & 0.592 & $0.034^{*}$ \\
\hline Education & 0.679 & 0.471 \\
\hline Marital Status & 0.667 & 0.466 \\
\hline Occupation & 0.633 & 0.190 \\
\hline Current Treatment & 0,520 & 0.628 \\
\hline Contraceptives & 0.567 & 0.331 \\
\hline Cancer Stadium & 0.687 & $0.046^{*}$ \\
\hline First Menstruation Age & 0.575 & 0.564 \\
\hline Age When Married & 0.494 & $0.014^{*}$ \\
\hline First Pregnancy Age & 0.682 & 0.724 \\
\hline Pregnancy Frequency & 0.592 & 0.414 \\
\hline Breastfeeding Period & 0.657 & 0.293 \\
\hline
\end{tabular}

Table 4 shows the result of linear regression. The factor contributing to the quality of life $(\mathrm{p}<0.05)$ was age with $\mathrm{p}$-value 0.034 , followed by age when married with $\mathrm{p}$-value 0.028 , result of anatomy-pathology (cancer stadium) with p-value 0.036 . The result of coefficient correlation mostly shows 0.060 value, indicating a strong relation with the quality of life. The result of coefficient correlation indicating strong correlation (0.60-0.799) was education, marital status, occupation, cancer stadium, first pregnancy age, and breastfeeding period. Meanwhile, the factors indicating moderately strong relation $(0.44-0.599)$ were respondent's age, current treatment, contraceptives, first menstruation, age when married, and pregnancy frequency.

\section{DISCUSSION}

The analysis result of parametrical bivariate shows a positively correlated factor to the quality of life of breast cancer patients is age with p-value 0.010. It is to be noted that, in this research, the age factor is within the range of 32 to 68 years old. In fact, 30 respondents are averagely aged 48.87 years old. This result shows age has a positive correlation with the quality of life of breast cancer patients, which is in line with Kwan et 1., (2017) arguing that younger ages show lower life quality compared to the elder ones. In addition, Gangane et al., 
Haris: Factors That Relevant to The Quality of Life of Breast Cancer Patients

(2017) elaborates that younger ages correlate with the quality of life of breast cancer patients. Roiland et al., (2011) shows that older patients show symptoms of change in the quality of life.

Reproduction factor in this research showing correlation is first pregnancy age and pregnancy frequency. First pregnancy age is negatively correlated with the quality of life of breast cancer patients with p-value 0.030 . The first youngest pregnancy age is 13 years old, while the oldest is 32 . The average of the first pregnancy age is 21.7 years old. The positively correlated pregnancy frequency with the quality of life of breast cancer patients with p-value 0.015. The least pregnancy frequency is once; meanwhile, the most is 14 , and the average is 3.63 (3 to 4 times). Existing research has not connected that reproduction factor with the quality of life of breast cancer patients. However, those two factors are strongly interrelated to the breast cancer incidents as argued by Rasoto et al., (2013). The reproduction factor strongly correlated to the breast cancer incident is the three times of pregnancy or more. Using Odds Ratio 0.7 or 0.7 times of chance to contract breast cancer for those who have been pregnant 3 to 4 times. However, first pregnancy age has 1.2 times higher of chances for mothers below 25 years old, and 1.6 times higher for 30 years old.

The linear regression analysis shows three factors contributing to the quality of life of breast cancer patients. Those factors are age ( $p$-value 0.034), age when married ( $p$-value 0.028), and result of anatomy pathology (cancer stadium). Two factors contributing to the determination of the quality of life of breast cancer patients are age and cancer stadium, according to Tsai et al., (2017). He claims that age, cancer condition, and current treatment are correlated to the quality of life of breast cancer patients. Kwan et al., (2010) elaborates that age and delay of treatment are highly contributive to the patient's quality of life, younger age shows lower score of quality of life related to advanced-stage of cancer or its severity. On the other hand, existing research has not linked age when married to the quality of life but 
treats it as risk factor of breast cancer instead. It is also correlated with first pregnancy age as put forward by Rasoto et al., (2013), saying that pregnancy age below 25 years old has a 1.2 times higher chances for breast cancer.

\section{CONCLUSION}

It is concluded that three factors contributing to the quality of life of breast cancer patients are age, age when married, and result of anatomy-pathology (cancer stadium). Meanwhile, first pregnancy age and pregnancy frequency also show correlation. Limitations in this research include descriptive method and the samples were only taken in the scope of visit houses and not in hospitals. Moreover, this research is a raw data in nature and thus requires further analysis on other factors correlating with the quality of life of breast cancer patients. On top of that, it is also necessary to come up with intervention efforts that may improve the quality of life of breast cancer patients. That said, these necessities are expected to be an interventional reference in improving the quality of life of breast cancer patients.

\section{ACKNOWLEDGEMENT}

This research is financially supported by Lembaga Pengelola Dana Pendidikan (LPDP) from the Ministry of Finance Republic of Indonesia and research grant from the Ministry of Research Technology and Higher Education through researcher's companion.

\section{REFERENCES}

Advence Breast Cancer Converence. (2016). Global Status of Advanced/ Metastatic Breast Cancer, 2005-2015 Decade Report, Final Report. Pfizer oncology, ABC3, European School of Oncology,

Anothaisintawee, et al., (2013). Risk Factors of Breast Cancer: A Systematic Review and Meta-Analysis. Asia Pasific Journal of Publich Health 25(5) 368-387. Sagepub.com DOI:10.1177/1010539513488795. 
Ardiana., Negara, H.W., \& Sutisna, M (2013). Analisis Faktor Risiko Reproduksi yang Berhubungan dengan Kejadian Kanker Payudara pada Wanita. Jurnal Keperawatan Padjajaran Vol 1 Nomor 2 Periode Agustus.

Chopra, I \& Kamal, K.M., (2012). A Systematic Review of Quality of Life Instruments In Long-Term Breast Cancer Survivor. Health and quality of life outcomes. 10:14 BioMed Central. http://www.hqlo.com/content/10/1/14.

Gangane, N et al., (2017). Quality of Life Determinants in Breast Cancer Patiens in Central Rural India, Asian Pacific Journal Of Cancer Prevention: APJCP [Asian Pac J Cancer Prev] 2017 Dec 29; Vol. 18 (12), pp. 3325-3332. Date of Electronic Publication: 2017 Dec 29.

Irawan, E., Rahayuwati, L., \& Yani, D (2017). Hubungan Penggunaan Terapi Modern Dan Komplementer Terhadap Kualitas Hidup Pasien Kanker Payudara Yang Menjalani Kemoterapi. Jurnal Keperawatan Padjadjaran vol 5 nomor 1 April.

James, F.R., Wootton S., Jacson, A., Wiseman, M, Copson, E.R., \& Cutress (2015). Obesity in breast cancer - What Is The Risk Factor? European Journal of Cancer 51, 075-720 http://dx.doi.org/10.1016/j.ejca.2015.01.057.

Kementrian Kesehatan (2016). Oktober, Bulan Peduli Kanker Payudara. Pusat Informasi dan Data kementerian Kesehatan.

Kim, M.S., Kim, S.Y., Kim J.H., Park, B., Choi, H.G.(2017). Depression In Breast Cancer Patients Have Undergonemastectomy: A national Cohort Study. PlosOne 12(4):e0175395. Htttps://doi.org/10.137/journal.pone.0175395.

Kwan, M et al., (2010). Quality of life among women recently diagnosed with invasive breast cancer: the pathway study. Breast Cancer Res Treat: 123:107-524. DOI 10.1007/s10549-010-0764-8.

Maly, R.C., Liu, Y., Liang, L.J., \& Ganz, P.A (2014). Quality of Life Over 5 Year After a Breast Cancer Diagnosis Among Low-Income Women: Effects of Race/ Ethnicity Patient-Physician Communication. Cancer March 15. DOI: 10.1002/cnc.29150.

$\mathrm{Ng}$, Chong et al (2015). Anxiety, Depression, perceived social support and quality of life in malaysian breast cancer patients: a 1-year prospective study. Health and Quality of life outcomes 13:205 DOI 10.1186/s12955-015-0101-7. BioMed Central.

Nurhasanah, S (2014). Analisis Pasien Kanker Payudara pada Setiap Siklus Kemoterapi di Ruang Kemoterapi Rumah Sakit Pendidikan Unpad Bandung. Universitas Padjadjaran Purkayastha, D., Venkateswaran, C., Nayar, K., Unnikrisnann, UG. (2017). Prevalence of Depresion in Breast Cancer Patient and Its Association with Quality of Life. The Indian Journal of Palliative Care. July 18 IP.202.177.173189. DOI:10.4103/IJPC.IJPC_6_17.

Rahayuwati, L., Ibrahim, K., \& Mardiah, W. (2016). Health Seeking Behavior on Breast Cancer Therapies: Patients' versus Providers' Views. J Community Public Health Nurs, 2(3), 2-6. 
Roiland., Rachel, A., Heidrich., \& Susan,M (2011). Symptom Cluster and Quality of Life in Older Adult Breast Cancer Survivor. Oncology Nursing Forum, Nov2011; 38(6): 672-680. (9p) (Journal Article - research, tables/charts) ISSN: 0190-535X PMID: 22037330 AN: 104637898.

Rosato, V et al., (2014). Reproductive and Hormonal Factors, Family History, and Breast Cancer According to The Hormonal Receptor Status, European Journal of Cancer Prevention 2014, 23:412-417 DOI: 10.1097/CEJ.0b013e3283639f7a (Placeholder1).

Sugiono. (2016). Metode Penelitian Kuantitatif dan Kualitatif Dan R\&D. Bandung: Alfabeta.

Tsai,H-Y., Kou, R., \& Choung,K-P (2017). Quality of Life of Breast Cancer Survivors Following Breast-Conserving Therapy Versus Mastectomy: A Multicenter Study in Taiwan. Japanese Journal of Clinical Oncology, 2017, 47(10) 909-918 doi: 10.1093/jjco/hyx099.

Yan, B et al (2016). Determinants of Quality of Life for Breast Cancer Patients in Shanghai, China. Plos One DOI: 10.137/journal.pone.0153714. 